\section{Star wars}

\section{Franco-German accord?}

THE disagreement at last month's summit meeting between France and West Germany over participation in the US star wars programme seems to be blowing over. President Francois Mitterrand seems to have offended Chancellor Helmut Kohl at the Bonn meeting by saying that France would not take part, and seems himself to have taken offence at West Germany's willingness, which was taken as a sign of disinterest in the alternative French proposal of a European programme of hightechnology research, called Eureka. It is now expected that these differences will melt away when Mitterrand visits Bonn later in the month, but meanwhile it has come to light that two major French companies are planning to go ahead with star wars research in any case. So what exactly did Mitterrand's gesture mean?

M. Pierre Aigrain, research director of Thomson-CSF, one of the two French companies suspected of star wars complicity, said last week that he "didn't know". And others, pointing to the electronics and armaments company's continuing heavy losses, suggested that if Thomson-CSF could (quietly) find a slice of the $\$ 26,000$ million star wars budget, nobody in France was going to complain too much.

Aigrain, himself an ex-minister (of research), agrees that, on the whole, Mitterrand is right to be wary of arrangements in which Europe would act merely as subcontractor to the United States. But would Thomson-CSF itself consider such deals? "That's something we would look at on a case by case basis", said Aigrain. His company is among the world leaders in higher power vacuum-tube technology. "If we were asked to develop a special high power tube, I don't know whether we'd say no. I think probably we'd consider it if the funding's all right and so on. A company will always react by thinking about its own profit." When it comes to research funding from abroad, however, a company would need government approval.

Aigrain considers, as does the French government, that in the Strategic Defense Initiative (SDI or star wars) programme, the United States "is at least as much looking for a way of advancing technology as it is in developing an active weapons system". In Europe, this technology should be developed by European cooperation, Aigrain believes, thus defending President Mitterrand's proposal of a major civil programme, Eureka, to match those aspects of SDI capable of civil application.

"The big problem is that until now, with the exception of the European programme of research in information technology (ESPRIT), Europe has been spending extremely little on joint technology programmes". Even ESPRIT is costing only onefiftieth of the SDI budget. Thus Mitterrand's Eureka “is a way to say we've no option but to spend a lot more money on advanced technology. As far as this is concerned I can only say I'm in favour of it', said Aigrain.

The money should not come from extra taxes, but from rechannelling existing, poorly-spent sums. In telecommunications systems, Europe spends more on research and development than the United States and Japan put together, according to Aigrain. But much of the spending is duplicated and "rather ineffective".

The problem with SDI for Europe, says Aigrain, is that the programme has been put under the military. "It's true in every country in the world that the defence establishment is usually the most efficient user of technological advance. One may not like it but it's true. The problem in Europe is that we don't have a military establishment at European level. but I don't think we should have this until we have a much greater level of political unity."

The most important spin-off from SDI will be in communications and systems, Aigrain believes. "It's obvious - people are always speaking of the basic weapons part of SDI but a much bigger challenge is the automatic collection of information, processing the data, making an intelligent system, says Aigrain. He believes the development and civilianization of such technology may be the biggest effect of SDI.

Robert Walgate

\title{
All change ahead in London
}

THE Royal Society of London seems to be well launched on a period of organizational change, with a new management structure, new people in top posts and with ambitions to exert more influence on public policy. The immediate occasion for the change is the retirement of Dr R.W.J. Keay from the post of executive secretary of the society with effect from 20 May.

Keay is to be succeeded by Dr Peter T. Warren, deputy secretary since 1977 . The society has taken this as an opportunity to equip itself with a middle management

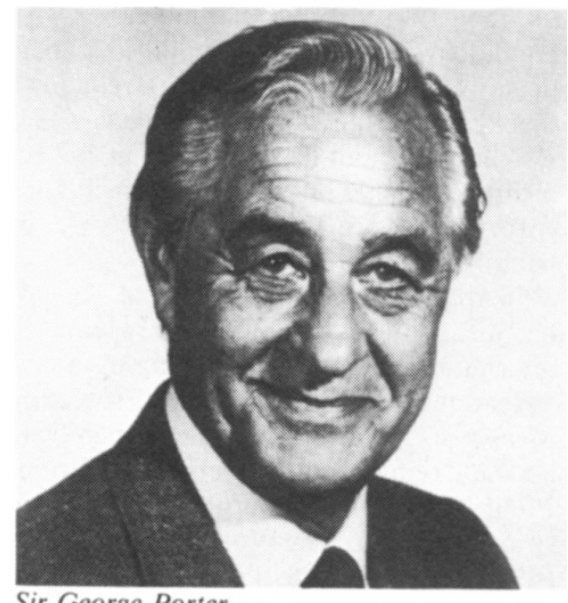

Sir George Porter.

structure. The post of deputy secretary has been abolished, but instead there will be three officials responsible for national, international and financial matters.

Mr Peter Cooper, a member of the society's staff for the past ten years, will be the assistant secretary responsible for national affairs, Mr S.J. Cox (now at the British Embassy in Washington) will look after international affairs while Mr N.B. Parfitt, now the society's finance officer, will be in charge of finance and administration. One of the officers of the society says that the need for the new structure has been appreciated for some time, but that the change has been delayed by lack of funds.

Among the new directions in which the society is embarking is that of providing a more systematic commentary on the condition of British science than has been possible by means of the ad hoc studies carried out by voluntary committees, which have nevertheless been a growing part of the society's work in the past five years.

The plan now is to set up a small unit, comprising perhaps three professional people, to compile a database describing the pattern of British academic research and eventually to produce analytical papers which, it is hoped, will guide the often acrimonious public debate about the scale and mechanisms of research support in Britain. To ensure the independence of this unit, whose acting head is Dr Peter Collins, the Royal Society plans to meet the costs out of its own funds, not from those supplied by the central government.

Meanwhile, the Royal Society is also preparing for one of its quinquennial changes at the top. Sir Andrew Huxley, president of the Royal Society for the past five years, will retire on 30 November and be succeeded by Sir George Porter, director of the Royal Institution since 1966, who shared a Nobel Prize in 1967 for his work on the use of lasers in the study of rapid chemical reactions. Porter plans to retire from the Royal Institution, but a date has not yet been fixed.

The effects of this change are, as always, unknowable. Sir Andrew Huxley, thought before his election as president to have been shy of public controversy, has been outspoken on a variety of issues, ranging from the Soviet treatment of scientists and the rights and wrongs of cladistics to the British government's regard for basic science. Dogged determination has been the watchword in the past five years.

Porter is more mercurial than Huxley, and has earned a reputation as a popularizer by means of his work with television, which fits in with some of the society's ambitions to improve the public presentation of science. 